\title{
UJI JARAK TANAM DAN IMPLIKASINYA TERHADAP PRODUKTIVITAS DAN INTENSITAS SERANGAN PENYAKIT PADA BEBERAPA VARIETAS JAGUNG HIBRIDA (Zea mays L.) DI KABUPATEN JEMBER
}

\author{
Plant Spacing And Implication Test On Productivity And Intensity Of Disease Attacks \\ On Some Hybrid Corn Varieties (Zea mays L.) In Kabupaten Jember
}

\author{
M. Iwan Wahyudi ${ }^{1}$ dan M. Ali Surahman ${ }^{2}$ \\ 1) Agroteknologi Fakultas Pertanian Universitas Muhammadiyah Jember \\ 2) Technology Development Assistant PT. Monsanto Indonesia \\ e-mail: iwan.wahyudi@unmuhjember.ac.id
}

\begin{abstract}
ABSTRAK
Produktivitas jagung sangat dipengaruhi oleh bahan tanam dan lingkungan tumbuh tanaman. Salah satu faktor yang menentukan optimalisasi iklim mikro untuk mendukung tumbuh kembang tanaman jagung yaitu jarak tanam. Variasi jarak tanam akan berimplikasi terhadap produktivitas dan menentukan tingkat serangan OPT tanaman jagung hibrida. Penelitian ini bertujuan untuk mengetahui pengaruh jarak tanam terhadap produktivitas tanaman dan intensitas serangan penyakit serta rebah. Design Penelitian menggunakan RAK faktorial dengan Varietas sebagai faktor pertama, dan Jarak tanam sebagai faktor kedua. Varietas terdiri atas 2 taraf yaitu V1 (DK771) dan V2 (DK95), sedangkan Jarak Tanam terdiri atas 5 taraf yaitu J1 $(54 \times 20 \mathrm{~cm}), \mathrm{J} 2(58 \times 20 \mathrm{~cm}), \mathrm{J} 3(64 \times 20 \mathrm{~cm}), \mathrm{J} 4(70 \times 20 \mathrm{~cm})$, dan $\mathrm{J} 5(78 \times 20 \mathrm{~cm})$. Perlakuan diulang tiga kali dan dilakukan di lima titik kecamatan di Kabupaten Jember dari Januari-Juni 2015. Hasil penelitian menunjukkan bahwa jarak tanam (populasi) berpengaruh sangat nyata terhadap hasil panen untuk semua varietas yang diujikan (DK771 dan DK95), tetapi interaksi antara varietas dengan populasi tidak signifikan terhadap hasil panen. DK771 dan DK95 mencapai potensi hasil tertinggi pada populasi 78.125 - 92.593 di area tadah hujan dan menurun seiring penurunan populasi. Populasi tanaman tidak berpengaruh nyata terhadap rebah batang maupun rebah akar, begitu juga dengan busuk pelepah dan busuk tongkol tidak secara nyata dipengaruhi oleh populasi tanaman. Adanya perbedaan intensitas serangan penyakit nyata diantara varietas terkait ketahanan genetic masing-masing hibrida.
\end{abstract}

Kata Kunci: Jarak Tanam, Penyakit, Produktivitas Tanaman, Varietas

\begin{abstract}
The productivity of maize is well known by planting materials and plant growing environments. One of the factors that determine the optimization of microclimate to support the growth of crops of maize is the spacing or planting distance. Variations in
\end{abstract}


plant spacing will have implications for productivity and detection of hybrid corn plant pests. This study aims to determine the effect of planting on crop productivity and disease attacks and falls. The research design used Factorial Randomize design with Varieties as the first factor, and plant spacing as a second factor. The varieties consist of 2 levels, namely V1 (DK771) and V2 (DK95), while Planting Distance consists of 6 levels ie J1 $(54 \times 20 \mathrm{~cm}), \mathrm{J} 2(58 \times 20 \mathrm{~cm}), \mathrm{J} 3(64 \times 20 \mathrm{~cm}), \mathrm{J} 4(70 \times 20 \mathrm{~cm})$, and $\mathrm{J} 5(78 \times 20 \mathrm{~cm})$. The treatment was repeated three times and was done in five districts in Jember District from January to June 2015. The results showed that the spacing was very high for all tested varieties (DK771 and DK95), but the interaction between varieties with insignificant amounts of yields. DK771 and DK95 achieved the highest potential yields in the 78,125-92,593 population in rain-fed areas and decreased as population declines. The plant population does not affect the fall of stem or the fall of roots, as well as the rot of midrib and the rot of cob is not real by the plant. There are things that can be done to differentiate the genetic of each hybrid.

Keywords: Planting Distance, Disease, Plant Productivity, Varieties

\section{PENDAHULUAN}

Jagung (Zea mays L.)merupakan salah satu komoditi potensial baik dalam kontribusinya sebagai bahan pangan maupun pakan. Kebutuhan jagung nasional diawal millennia yang dipenuhi melalui import sebesar 1.26 Juta Ton/Tahun (BPS, 2005) yang menunjukkan kebutuhan jagung nasional meningkat terutama untuk pakan dan industry. Kebutuhan pakan dan industry saat ini menyerap 50\% kebutuhan jagung, sehingga menuntut adanya upaya peningkatan produksi jagung (Jumakir dan Endrizal, 2002) baik melalui perluasan areal tanam maupun peningkatan produktivitas tanaman.

Produktivitas jagung di Indonesia masih tergolong rendah dibandingkan dengan potensi hasil tanaman tersebut yaitu hanya sekitar 5.1Ton/Ha dari potensi hasilnya yang bisa mencapai 10-12 Ton/Ha pipilan kering (BPS, 2018). Angka ini diperoleh Tahun 2015 untuk luasan panen jagung 3.8 Juta Ha dengan jumlah produksi 19.6 Juta Ton. Jawa Timur sebagai salah satu penyumbang jagung sekitar $31 \%$ nasional pada 2015 juga memiiki rata-rata produktivitas yang rendah yaitu 5 Ton/Ha (BPS Jatim, 2018). Kondisi yang sama juga terjadi di Kabupaten Jember dengan tingkat produktivitas sebesar 6.4 Ton/Ha, sedikit diatas rata-rata nasional (BPS Jatim,2018). 
Rendahnya produktivitas jagung di Indonesia pada umumnya disebabkan oleh faktor kultur teknis termasuk didalamnya ketersediaan benih unggul, kondisi iklim mikro, manajemen nutrisi, dan pengelolaan Organisme Pengganggu Tanaman (OPT) yang belum optimal. Iklim mikro sangat menentukan keberhasilan budidaya karena terkait dengan lingkungan tumbuh yang sesuai seperti suhu, intensitas cahaya, dan kelembapan udara.

Populasi tanaman sangat berpengaruh terhadap kondisi iklim mikro dan kompetisi terutama intensitas cahaya dan kelembapan. Tingkat populasi optimum akan memberikan dampak positif terhadap produktivitas tanaman. Beberapa hasil penelitian dan aktual hasil panen di beberapa Negara seperti Mexico, menunjukkan adanya peningkatan hasil dengan penambahan populasi hingga lebih dari 100.000 tanaman/Ha (Monsanto Indonesia TD Team, 2013). Data historical di Amerika Serikat menunjukkan adanya peningkatan hasil produksi jagung dengan penambahan populasi selama kurun waktu 100 Tahun (1900-2000) yaitu dari populasi 12.50070.000/Ha dengan pencapaian peningkatan hasil panen dari 1.7 Ton/Ha pada 1900 menjadi 10. 8 Ton/Ha di Tahun 2000 (USDA NASS query, Duvick 1999 dalam Monsanto Indonesia TD Team, 2013).

Namun demikian, penambahan populasi tidak selalu memberikan dampak positif terhadap produktivitas tanaman jagung. Populasi tanaman yang berlebihan akan menurunkan produktivitas jagung karena adanya kompetisi baik terkait unsur hara, cahaya matahari, dan kelembapan lingkungan tumbuh (Cekaman lingkungan) (Irfan, 1999 dalam Baiq, 2015). Sebaliknya, apabila populasi tanaman terlalu rendah akan menurunkan produktivitas jagung karena energy matahari banyak terbuang atau hilang ke area lahan selain adanya pengurangan potensi hasil per satuan luas karena populasi tanaman yang terlalu sedikit.

Produksi per satuan luas akan meningkat sejalan dengan peningkatan populasi, namun setelah kompetisi berlangsung maka produksi akan menurun (Harjadi, 1989). Untuk itu diperlukan pengujian jumlah populasi optimum per varietas yang akan ditanam dengan mempertimbangkan faktor genetic, ketersediaan nutrisi, cekaman lingkungan, ketersediaan air, dan intensitas cahaya matahari. 
Adanya karakteristik individu yang berbeda dari setiap varietas akan menjadi faktor penting dalam penentuan jarak tanam yang berimplikasi terhadap jumlah populasi. Selain itu, keberadaan nutrisi yang menopang setiap penambahan populasi juga penting untuk diperhatikan. Jumin (2010) menyatakan bahwa pertumbuhan relatif dan hasil bersih foto-sintesa per unit daun sangat ditentukan oleh jumlah populasi tanaman tiap luas lahan. Hal ini berhubungan erat dengan penangkapan dan pengikatan energi surya sebagai masukkan energi (input energy) maupun ketersediaan hara dan air dalam tanah.

Penelitian ini bertujuan untuk mengetahui jarak tanam (populasi) optimum beberapa varietas Hibrida di lahan tadah hujan di kabupaten Jember, dan untuk mengetahui implikasi dari kepadatan populasi terhadap intensitas penyakit utama tanaman jagung.

\section{METODE PENELITIAN}

Penelitian ini dilaksanakan di lahan tadah hujan milik petani di 5 kecamatan Wilayah Kabupaten Jember yaitu Jenggawah, Tempurejo, Balung, Kencong, dan Ambulu pada Bulan Januari-Juni 2015. Rancangan percobaan menggunakan Rancangan Acak Kelompok Faktorial 2x5 dengan 3 ulangan sebagai block. Faktor pertama yaitu varietas terdiri atas V1 (DK771) dan V2 (DK95). Faktor kedua adalah jarak tanam terdiri atas 5 taraf yaitu: J1 (54x20cm/92.593 Tanaman/Ha), J2 $(58 \times 20 \mathrm{~cm} / 86.207$ Tanaman/Ha), J3 $\quad(64 \times 20 \mathrm{~cm} / 78.125 \quad$ Tanaman/Ha $), \quad J 4$ (70x20cm/71.429 Tanaman/Ha), dan J5 (78x20cm/64.103 Tanaman/Ha). Parameter pengamatan meliputi Hasil Panen (Yield) dikonversi menjadi hasil pipilan kering KA $15 \%$, \% stalk lodging atau rebah batang, \% root lodging/Rebah akar, Tingkat serangan Busuk pelepah Rhizoctonia solani dan Tingkat serangan busuk tongkol. Data hasil panen diambil pada saat waktu panen (masak fisiologis) dan diambil dari 4 baris tengah ( 4 dari 6 baris per plot dengan panjang plot 10m). Data tingkat serangan penyakit dan lodging diamati saat 80-85 HST dari 4 baris tengah (4 dari 6 baris per

plot dengan panjang plot $10 \mathrm{~m})$. Analisa data menggunakan Analysis of Varian 
(ANOVA) pada taraf 5\% dan apabila terdapat beda nyata akan diuji lebih lanjut menggunakan Uji BNT dengan tingkat kepercayaan 95\%. Untuk membangun kerangka awal hasil penelitian, dilakukan analisis regresi korelasi untuk mengetahui pengaruh kepadatan populasi terhadap yield (hasil panen).

Pelaksanaan penelitian dimulai dengan persiapan lahan dengan metode TOT dan membuat plot sepanjang 10m dengan lebar menyesuaikan jarak tanam (jumlah baris per plot adalah 6 baris). Jalan pengamatan dibuat $1.5 \mathrm{~m}$ per block dan dilakukan penanaman dengan 2 benih per lubang. Benih mendapatkan seed treatment menggunakan insektisida Gauco dengan dosis sesuai rekomendasi pabrik dan fungisida Acrobat dengan dosis $4.5 \mathrm{cc} / \mathrm{Kg}$ benih. Selanjutnya, Penjarangan dilakukan maksimal 15 HST (Hari Setelah Tanam) dengan menyisakan 1 tanaman per lubang dan total populasi harus diatas 90\%. Pemupukan menggunakan Urea $(306 \mathrm{Kg} / \mathrm{Ha})$, NPK Phonska (400Kg/Ha), dan SP36 (20Kg/Ha) dengan perbandingan kandungan $\mathrm{N}: \mathrm{P}: \mathrm{K}$ yaitu 200.8Kg:67.2Kg:60 Kg. Jumlah tersebut diaplikasikan konstan untuk setiap perlakuan dan dilakukan sebanyak 3 waktu aplikasi yaitu 0 HST (100\% P dan $\mathrm{K}$ serta $25 \% \mathrm{~N}), 15-20 \mathrm{HST}(50 \% \mathrm{~N})$ dan $30 \mathrm{HST}(25 \% \mathrm{~N})$. Pengendalian gulma dilakukan secara kimiawi dengan Atrazin dan mezotrion saat umur tanaman 20 HST. Sedangkan pengendalian OPT hanya di fokuskan untuk insect.

\section{HASIL DAN PEMBAHASAN}

Berdasarkan hasil pengambilan data dan analisis korelasi dan regresi didapatkan bahwa hasil panen jagung hibrida di lokasi tadah hujan 5 kecamatan di Kabupaten Jember memiliki korelasi yang sangat signifikan dengan tingkat kepadatan populasi. Nilai R square $85.2 \%$ menunjukkan bahwa tingkat kepadatan populasi mempengaruhi hasil panen sebesar 85.2\%. Sedangkan tHitung bernilai positif 6.79 menunjukkan bahwa semakin meningkat kepadatan populasi tanaman jagung maka berpotensi untuk meningkatkan hasil panen. Hasil analisis regresi dan korelasi tersebut sejalan dengan hasil analisis varian pengaruh dari varietas dan jarak tanam terhadap peningkatan hasil panen tanaman jagung (Tabel 1). Hasil ini juga sejalan dengan hasil penelitian Yulisma (2011) dan Baiq (2015) yang menyatakan bahwa 
penambahan populasi akan meningkatkan bahan kering tanaman sampai pada titik tertentu dan mengalami penurunan setelah mencapai populasi maksimum (40x40Cm).

Hasil penelitian Sutriyono (2001) dan Tabri (2013) juga mengindikasikan hal yang sama yaitu produksi bahan kering yang tinggi dicapai pada kepadatan populasi yang tinggi. Gardner et al. (1991), menyatakan bahwa populasi tanaman berpengaruh terhadap potensi hasil tanaman jagung terkait dengan pemanfaatan energy matahari dan kompetisi serta daya dukung lingkungan. Harahap dan Siagian (2001) juga menyatakan bahwa peningkatan populasi akan menekan laju evaporasi potensial, sehingga efisiensi pemanfaatan air akan meningkat.

Hasil rangkuman analisis varian dari beberapa variable pengamatan disajikan pada table 1 .

Tabel 1. Analysis of Varians pengaruh dari varietas dan jarak tanam terhadap peningkatan hasil panen tanaman jagung

\begin{tabular}{lc}
\hline \multicolumn{1}{c}{ Variabel } & F Hitung \\
\hline Produksi Tanaman/Yield & $4.67^{* *}$ \\
Rebah Batang & $0.97 \mathrm{~ns}$ \\
Rebah Akar & $0.59 \mathrm{~ns}$ \\
Busuk Pelepah & $2.03 \mathrm{~ns}$ \\
Busuk Tongkol/Earmix & $1.61 \mathrm{~ns}$ \\
\hline
\end{tabular}

Keterangan $=\mathrm{ns}:$ Tidak Berbeda Nyata, ${ }^{*}:$ Berbeda Nyata, ${ }^{* *}:$ Berbeda Sangat Nyata

Jenis hibrida berbeda nyata dalam perolehan hasil panen pada tingkat populasi yang sama dan ditunjukkan lebih detail dari hasil uji lanjut BNT dengan tingkat kepercayaan 95\% (Tabel 2) . Hal ini berkaitan dengan potensi genetic masing-masing hibrida berbeda yaitu DK771 sebagai varietas pengembangan terbaru memiliki potensi yield (hasil panen) lebih tinggi dibanding DK95.

Jarak tanam (kepadatan populasi) sangat nyata berpengaruh terhadap hasil panen baik untuk varietas DK771 maupun DK95. Namun demikian, interaksi antara varietas dan perlakuan jarak tanam tidak signifikan terhadap hasil panen. 
Tabel 2. Pengaruh Varietas dan Jarak Tanam terhadap Hasil Tanaman Jagung

\begin{tabular}{clcc}
\hline Hybrid & Jarak tanam & AVG Yield (MT/Ha) & BNT*AVG \\
\hline DK771 & $78 \times 20$ & 6.52 & $7.26 \mathrm{a}$ \\
& $70 \times 20$ & 6.98 & $7.72 \mathrm{ab}$ \\
& $64 \times 20$ & 7.51 & $8.25 \mathrm{bc}$ \\
& $58 \times 20$ & 7.78 & $8.52 \mathrm{c}$ \\
& $54 \times 20$ & 7.98 & $8.73 \mathrm{c}$ \\
\hline DK95 & $78 \times 20$ & 6.28 & $7.02 \mathrm{a}$ \\
& $70 \times 20$ & 6.70 & $7.44 \mathrm{ab}$ \\
& $64 \times 20$ & 7.08 & $7.82 \mathrm{bc}$ \\
& $58 \times 20$ & 7.41 & $8.15 \mathrm{bc}$ \\
& $54 \times 20$ & 7.52 & $8.26 \mathrm{c}$ \\
\hline Keterangan : & Angka-angka yang disertai dengan huruf yang \\
& \multicolumn{3}{c}{ sama menunjukkan berbeda tidak nyata menurut }
\end{tabular}

Produksi tertinggi dicapai oleh varietas DK771 pada penggunaan jarak tanam 54x20Cm (populasi 92.953 tanaman/Ha) yaitu 7.98 Ton/Ha. Hasil ini tidak berbeda nyata dengan perolehan hasil panen apabila menggunakan jarak tanam $58 \times 20 \mathrm{Cm}$ (populasi 86.207 tanaman/Ha) dan 64x20Cm (populasi 78.125/Ha). Produksi DK771 mulai mengalami penurunan hasil panen pada penggunaan jarak tanam $70 \times 20 \mathrm{Cm}$ (populasi 71.429 tanaman/Ha) dan $78 \times 20 \mathrm{Cm}$ (populasi 64.103 tanaman/Ha). Berdasarkan hasil tersebut, bisa dinyatakan bahwa varietas DK771 memiliki potensi hasil panen tertinggi dengan penggunaan jarak tanam optimum antara 58-64x20Cm atau kepadatan populasi antara 78.125-92.953 tanaman/Ha. Namun demikian, untuk rekomendasi ke petani diperlukan pertimbangan nilai ekonomi sehingga disarankan untuk menggunakan populasi yang terendah pada potensi hasil yang sama yaitu jarak tanam $64 \times 20 \mathrm{Cm}$. hal ini erat kaitannya dengan jumlah penggunaan benih dan masih mahalnya benih jagung hibrida saat ini.

Varietas DK95 mendapatkan produksi tertinggi pada perlakuan jarak tanam 54x20Cm (populasi 92.953 tanaman/Ha) yaitu 7.52 Ton/Ha. Trend respon varietas DK95 terhadap perlakuan jarak tanam memiliki pola yang sama dengan varietas DK771 yaitu mengalami hasil optimum pada tingkat kepadatan populasi antara 
78.125-92.953 tanaman/Ha dan menurun produksinya pada pengurangan tingkat populasi antara 64.103-71.429 tanaman/Ha (Gambar 1).

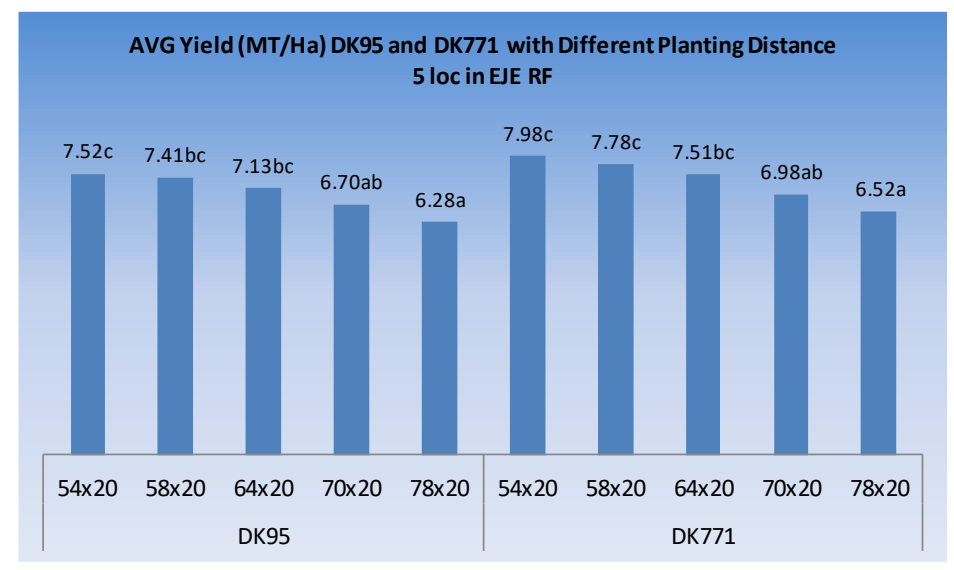

Gambar 1. Hasil panen DK771 dan DK95 dengan perlakuan beberapa jarak tanam

Perlakuan jarak tanam dan varietas tidak berpengaruh secara nyata terhadap tingkat rebah batang tanaman jagung di 5 lokasi percobaan (Tabel 1). Berdasarkan analisis varian, terdapat perbedaan yang sangat nyata tingkat rebah batang (stalk lodging) diantara 5 lokasi (Ulangan) yang dicobakan. Hal ini menunjukkan bahwa rebah batang tidak disebabkan oleh faktor varietas maupun jarak tanam, tetapi lebih disebabkan oleh pengaruh lingkungan tumbuh seperti tingkat kecepatan angin dan jenis tanah sebagai media tumbuh.

Berdasarkan Gambar 2, terlihat bahwa terjadi kecenderungan penurunan tingkat rebah batang sejalan dengan pengurangan populasi tanaman jagung, meskipun secara statistic tidak signifikan. Hal ini disebabkan adanya peningkatan populasi akan mengurangi diameter batang dan meningkatkan tinggi tanaman. Fenomena ini juga terjadi pada penelitian Baiq dan Awaludin (2015) yang menunjukkan adanya peningkatan tinggi tanaman sejalan dengan peningkatan populasi. Sudjana et al, 1991 dalam Effendi, 2004 menyatakan bahwa penambahan populasi per Ha akan menyebabkan meningkatnya rebah baik batang maupun akar. Adanya tingkat populasi yang tinggi menyebabkan kompetisi cahaya dan berdampak pada akumulasi auksin di apical sehingga pertumbuhan kesamping berkurang dan keragaan batangpun berkurang. Implikasinya ketahanan batang untuk rebah juga akan semakin berkurang. 


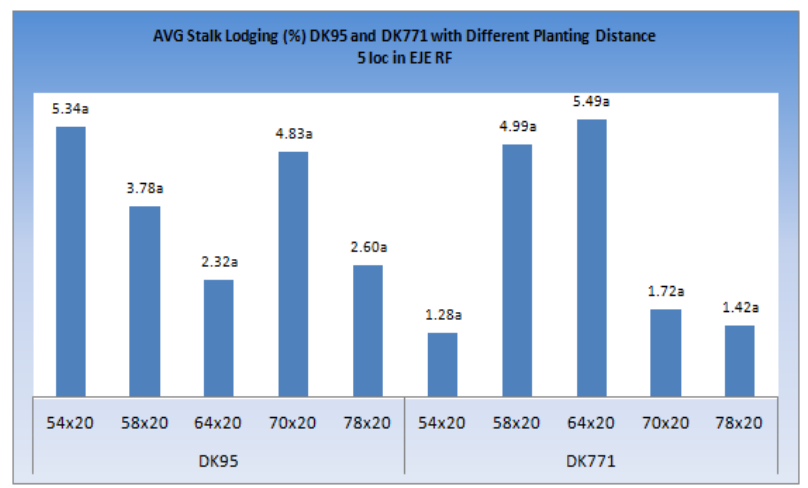

Gambar 2. Tingkat Rebah Batang Varietas DK771 dan DK95 pada Jarak Tanam Berbeda

Kondisi yang sama juga terjadi pada persentase rebah akar untuk kedua varietas yang diuji pada jarak tanam berbeda (Tabel 1 dan Gambar 3).

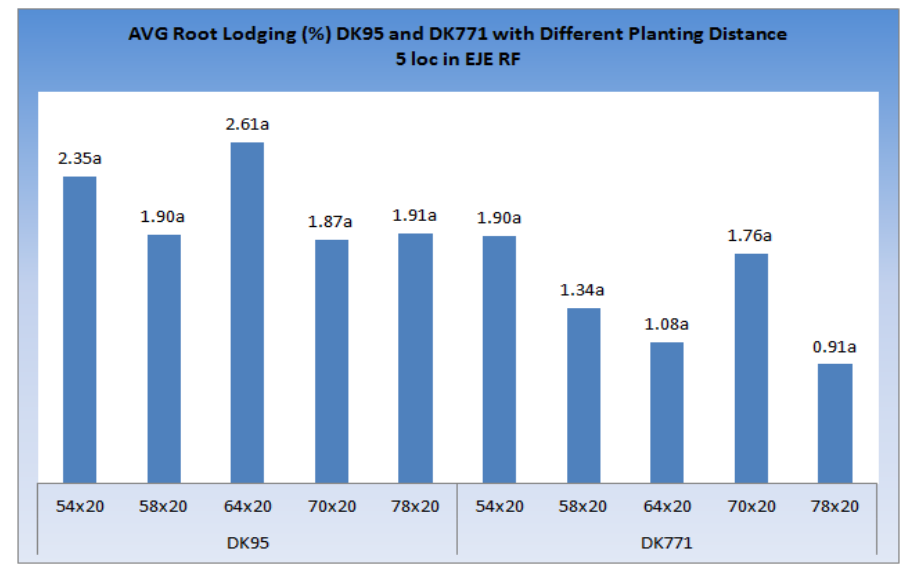

Gambar 3. Tingkat Rebah Akar Varietas DK771 dan DK95 pada Jarak Tanam Berbeda

Tingkat populasi tanaman jagung menentukan tingkat serangan OPT terkait dengan kelembapan dan cahaya serta suhu disekitar lingkungan tumbuh tanaman. Hasil analisis varian intensitas serangan busuk pelepah Rhizoctonia solani menunjukkan tidak ada pengaruh siginifikan untuk seluruh taraf jarak tanam yang dicobakan namun berbeda sangat nyata pada varietas dan lokasi percobaan. Peningkatan jumlah populasi tanaman jagung tidak diikuti oleh peningkatan tingkat serangan cendawan Rhizoctonia solani baik pada varietas DK771 maupun DK95. Artinya bahwa peningkatan populasi pada kedua varietas tersebut tidak menimbulkan 
perubahan siginifikan terhadap iklim mikro yang sesuai terhadap perkembangan sporulasi cendawan.

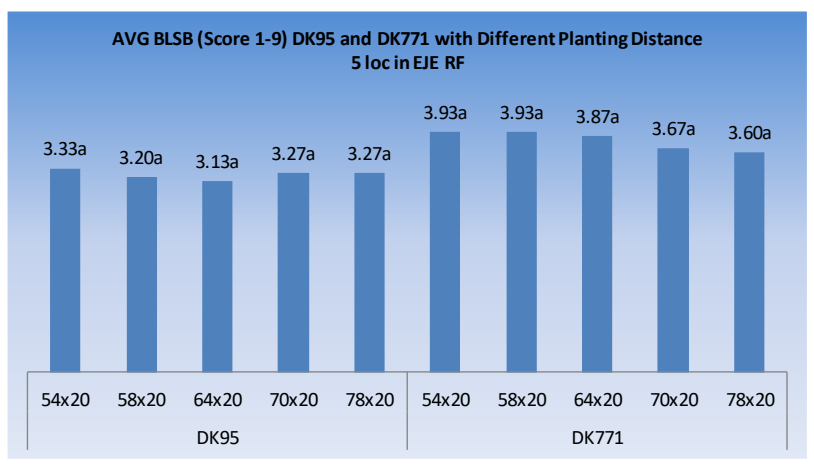

Gambar 4. Tingkat Serangan Busuk Pelepah DK771 dan DK95 pada Tingkat Populasi Berbeda

Tingkat serangan busuk pelepah pada varietas DK771 dan DK95 cenderung menurun dengan berkurangnya populasi tanaman meskipun secara statistik tidak signifikan (Gambar 4). Hal ini menunjukkan bahwa peningkatan populasi pada kondisi tertentu beresiko meningkatkan intensitas serangan cendawan termasuk busuk pelepah. Pengamatan intensitas serangan busuk pelepah dilakukan dengan scoring tingkat serangan (1-9) dimana angka 1 menunjukkan tanaman tanpa serangan dan 9 adalah serangan paling parah yang menyebabkan seluruh tanaman mati. Varietas DK95 mendapatkan score antara 3.13-3.33 (serangan tidak membahayakan), sedangkan DK771 memiliki range tingkat serangan antara 3.6-3.98. angka ini sudah mendekati menghawatirkan karena pada range 5, tingkat serangan busuk pelepah sudah memberikan kerugian secara ekonomi. Berdasarkan data tersebut, secara genetik DK95 memiliki tingkat resistensi lebih tinggi dari pada DK771 terhadap serangan busuk pelepah. Hal ini terbukti dari tingkat serangan busuk pelepah DK95 yang secara nyata lebih rendah dibandingkan DK771 pada jarak tanam yang sama. Adanya variasi score busuk pelepah diantara 5 lokasi percobaan menunjukkan adanya lokasi endemic dan non endemic dari Rhizoctonia solani sehingga berpengaruh terhadap tingkat serangan. 
Intensitas serangan ear rot complex atau busuk tongkol pada pengujian varietas DK95 dan DK771 yang ditanam dengan berbagai tingkat populasi menunjukkan tidak berbeda nyata pada semua perlakuan jarak tanam, namun berbeda nyata pada varietas dan lokasi percobaan.

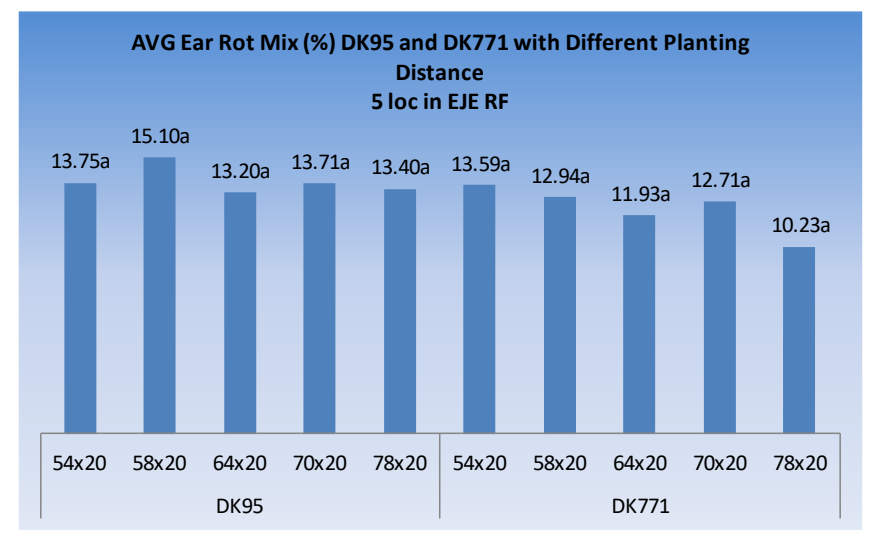

Gambar 5. Tingkat Serangan Busuk Pelepah DK771 dan DK95 pada Tingkat Populasi Berbeda

Trend intensitas serangan busuk tongkol pada semua varietas hampir sama dengan busuk pelepah yaitu cenderung menurun dengan pengurangan populasi tanaman meskipun tidak signifikan secara statistik (Gambar 5). Hal ini menunjukkan bahwa penambahan populasi tidak secara nyata berpengaruh terhadap peningkatan intensitas serangan busuk tongkol. Varietas DK95 secara nyata lebih rentan terserang busuk tongkol dibandingkan DK771 pada jarak tanam yang sama. Hal ini berkaitan dengan karakter genetik dimana DK771 lebih tahan terhadap busuk tongkol dibandingkan dengan DK95. Tingkat serangan busuk tongkol sangat bervariasi pada 5 lokasi percobaan disebabkan karena factor lingkungan yang berkaitan dengan endemik tidaknya lokasi percobaan terhadap penyakit busuk tongkol.

Berdasarkan data intensitas serangan penyakit busuk pelepah dan busuk tongkol diatas, bisa ditarik benang merah bahwa tingkat populasi tanaman jagung tidak mempengaruhi secara nyata terhadap peningkatan serangan keduanya. Tingkat serangan kedua penyakit tersebut lebih ditentukan oleh ketahanan varietas jagung dan 
lingkungan tumbuh apakah endemic atau tidak dari cendawan penyebab busuk pelepah dan busuk tongkol.

\section{KESIMPULAN}

1. Jarak tanam (kepadatan populasi) sangat nyata berpengaruh terhadap hasil panen baik untuk varietas DK771 maupun DK95.

2. Varietas DK95 dan DK771 memiliki hasil panen optimum pada tingkat kepadatan populasi antara 78.125-92.953 tanaman/Ha dan menurun produksinya pada pengurangan tingkat populasi antara 64.103-71.429 tanaman/Ha.

3. Rekomendasi jarak tanam optimum secara ekonomi untuk varietas DK95 dan DK771 adalah 64x20Cm.

4. Tingkat kepadatan populasi tidak berpengaruh secara nyata terhadap tingkat serangan busuk pelepah dan busuk tongkol serta rebah baik batang maupun akar.

5. Tingkat serangan busuk pelepah dan busuk tongkol lebih ditentukan oleh resistensi varietas secara genetic dan lingkungan tumbuh tanaman jagung.

\section{DAFTAR PUSTAKA}

Badan Pusat Statistik, 2018. https://www.bps.go.id/subject/53/tanamanpangan.html\#subjekViewTab3

Erawati Baiq dan Awaludin H, 2015. Pengaruh Jarak Tanam terhadap Pertumbuhan dan Hasil Beberapa Varietas Jagung Hibrida di Kawasan Pengembangan Jagung Kabupaten Sumbawa . Prosiding Seminar Nasional Inovasi Teknologi PertanianBanjarbaru, 20 Juli 2016

Efendi, F. B, 2004. Uji Beberapa Varietas Jagung (Zea Mays L.) Hibrida Pada Tingkat Populasi Tanaman Yang Berbeda. Ipb, Bogor.

Gardner, F. P., R. B. Pearce \& R.L. Mitchell. 1991. Fisiologi Tanaman Budidaya (Terjemahan Herawati Susilo). UI- Press, Jakarta.

Harjadi, S.S., 1989. Pengantar Agronomi. Penerbit Gramedia, Jakarta 
Jumakir dan Endrizal, 2009. Produktivitas Pertanaman Jagung di Lahan Pasang Surut Kabupaten Tanjung Jabung Barat, Provinsi Jambi. Balai Pengkajian Teknologi Pertanian Jambi.

Jumin, H. B. 2010. Dasar-dasar Agronomi. Rajawali Pers. Jakarta.

Monsanto Indonesia, Technology Development, 2013. Indonesia Plant population Trial Protocol, Jakarta.

Siagian, M. H., Harahap, R. 2001. Pengaruh Pemupukan dan Populasi Tanaman Jagung Terhadap Produksi Baby Corn Pada Tanah Podsolik Merah Kuning. Puslitbang Biologi. LIPI - Bogor

Sutriyono. 2001. Pengaruh kepadatan tanam awal jagung sebagai pakan ternak terhadap produksi biji dan hijauan serta penaambahan bobot badan domba. Tesis Fakultas Pascasarjana. Institut Pertanian Bogor.

Tabri, F., 2013. Pengaruh Kepadatan Populasi Terhadap Hasil Dua Varietas Jagung Hibrida. Balai Penelitian Serealia. Seminar Nasional Serealia, 2013

Yulisma, 2011. Pertumbuhan dan Hasil Beberapa Varietas Jagung pada Berbagai Jarak Tanam. Penelitian Pertanian Tanaman Pangan. Vol.3 No.2. 2011 